\title{
PERAN DESA WISATA KAMPUNG SUSU DINASTY DALAM MENINGKATKAN PENDAPATAN PEMERINTAH DESA \\ DAN KESEJAHTERAAN MASYARAKAT DESA SIDEM KECAMATAN GONDANG KABUPATEN TULUNGAGUNG \\ Nihla Hikmania ${ }^{1}$ \\ UIN Sunan Ampel Surabaya | niaseyrow@gmail.com
}

\begin{abstract}
Abstrak: Peran Desa Wisata Kampung Susu Dinasty Dalam Meningkatkan Pendapatan Pemerintah Desa dan Kesejahteraan Masyarakat Desa Sidem Kecamatan Gondang Kabupaten Tulungagung ini merupakan hasil penelitian yang menjawab pertanyaan tentang bagaimana peran desa wisata kampung susu dinasty dalam meningkatkan kesejahteraan masyarakat dan pendapatan Desa Sidem Kecamatan Gondang Kabupaten Tulungagung. Metodologi penelitian yang digunakan adalah pendekatan kualitatif deskriptif dengan jenis penelitian pada studi kasus objek. Pengumpulan data dilakukan menggunakan cara wawancara kepada informan dalam penelitian ini yaitu pengelola desa wisata, perangkat desa, pekerja/karyawan desa wisata, konsumen/wisatawan desa wisata dan masyarakat desa. Hasil penelitian yang diperoleh bahwa Desa Wisata Kampung Susu Dinasty mampu meningkatkan pendapatan Desa Sidem. Dalam proses dimulai dengan pengembangan desa ini akan menjadikan masyarakat Desa Sidem sebagai seumber daya manusia berupa tenaga kerja, dengan demikian akan membantu kesejahteraan masyarakat Desa Sidem. Berkembangnya desa wisata di Desa Sidem akan membantu Pemerintah Desa dalam meningkatkan Pendapatan Asli Desa (PAD). Namun ada satu hal yang menjadi hambatan dalam pengembangan desa wisata tersebut diantaranya keterampilan yang dimiliki masyarakat untuk menjadi pekerja/karyawan di kampung susu dinasty. Untuk kontribusi peningkatan pendapatan desa Pemerintah Desa Sidem sendiri sudah fokus terhadap peningkatan pembangunan fisik dan non fisik hingga saat ini.
\end{abstract}

Keywords: Peran Desa Wisata; Kesejahteraan Masyarakat; Pendapatan Desa. 


\section{Pendahuluan}

Pertumbuhan ekonomi Indonesia dapat dikatakan memiliki peluang baik di tahun 2018. Melimpahnya sarana infrastruktur serta tenaga kerja yang secara langsung meningkat cukup memberikan kabar baik terhadap sistem ekonomi Indonesia. Disisi lain investasi swasta meningkat dengan ditopangnya proyek infrastruktur. Selain itu faktor ekspor diharapkan memperkuat daya saing.

Perkembangan dan pembangunan ekonomi juga tidak lepas dari kondisi fisik, letak geografis suatu negara tersebut dan kualitas sumber Daya Manusia (SDM), kualitas Sumber Daya Alam (SDA), sosial budaya, dan kondisi awal ekonominya. Disisi lain faktor eksternal perkembangan dan pembangunan ekonomi diantaranya kondisi politik, keamanan global, dan perkembangan teknologi. ${ }^{1}$

Badan Pusat Statistik (BPS) sudah merilis hasil dari pertumbuhan ekonomi dalam kuartal I mencapai angka sebesar 5,06 persen. Angka tersebut lebih unggul dibanding dengan pertumbuhan ekonomi pada kuartal I tahun 2017 sebesar 5,01 persen. Bisa dikatakan pertumbuhan ekonomi kuartal I 2018 didukung harga komuditas migas dan nonmigas pada pasar internasional yang sedang meningkat. Kemudian kondisi ekonomi global turut pula berkontribusi, meskipun laju pertumbuhannya masih rendah dibanding kuartal pada tahun sebelumnya. Selanjutnya pada tingkat inflasi pada kuartal I 2018 masih terjaga pada angka 3,40 persen. ${ }^{2}$

Sektor Pariwisata sangat berperan aktif dan penting dalam meningkatkan perekonomian indonesia. Tahun 2014 tercatat kontribusi pariwisata terhadap PDB (Produk Domestik Bruto) sebesar 9,3\% dan terhadap lapangan kerja nasional sebesar 8,4\% atau sebanyak 9,8 juta lapangan kerja. ${ }^{3}$ Pada tahun 2014 tercatat pula 9,4 juta wisatawan mancanegara (wisman) dengan devisa sebesar USD 11,2 miliar. Tahun 2013 tercatat 203 juta perjalanan wisatawan nusantara (wisnus) dengan pengeluaran total sebesar Rp. 117,8 triliun. ${ }^{4}$

Kemudian desa wisata di Indonesia saat ini telah berkembang

\footnotetext{
${ }^{1}$ Aunur Rofiq, Pertumbuhan Ekonomi Dan Kemiskinan, (Jakarta; Republika), 18

${ }^{2}$ bps.go.id, diakses tanggal 10 Desember 201815.53

${ }^{3}$ Worl Travel and Tourism Council, Travel \& Tourism Economic Impact 2015, (Indonesia; London WTTC) 2015, 41
} 
dengan baik. Desa wisata merupakan kawasan yang memiliki beberapa kearifan lokal seperti adat istiadat, budaya, dan potensi yang dimilki di desa tersebut. Kemudian dikelola untuk menjadikan suatu daya tarik wisata sesuai dengan kemampuan desa tersebut, kemudian akan ditunjukan sebagai kepentingan sosial dan ekonomi masyarakat di linkungan desa tersebut.

Desa wisata juga merupakan suatu kawasan berupa lingkungan pedesaan yang didalamnya memiliki daya tarik wisata berbasis suatu kearifan lokal seperti budaya, adat-istiadat, serta melimpahnya kekayaan alam yang memiliki suatu keunikan, keasrian, dan keaslian berupa ciri khas suasana desa. Kawasan pedesaan yang sudah dikelola menjadi desa wisata memiliki beberapa gabungan atau lebih dari satu beberapa daya tarik wisata, misalnya gabungan dari beberapa agrowisata, ecotourism dan wisata kebudayaannya dalam satu kawasan desa wisata yang berbasis edukasi. ${ }^{5}$

Jawa Timur saat ini memiliki desa wisata yang sangat beragam dan sudah mulai berkembang pesat dengan kekayaan alam yang melimpah tanpa menghilangkan kearifan lokal suatu daerah tersebut. Berikut ini data desa wisata yang dimiliki oleh Provinsi Jawa Timur antara lain:

Tabel 1.1

Desa Wisata Jawa Timur Tahun 2017

\begin{tabular}{|r|l|l|}
\hline \multicolumn{1}{|c|}{ No Nama Desa Wisata } & \multicolumn{1}{c|}{ Tempat } \\
\hline 1. & Kwanyar & Kabupaten Bangkalan \\
\hline 2. & Bangsring & Kabupaten Banyuwangi \\
\hline 3. & Kemiren & Kabupaten Banyuwangi \\
\hline 4. & Rajegwesi & Kabupaten Banyuwangi \\
\hline 5. & Sumberejo & Kota Batu \\
\hline 6. & Tulungrejo & Kota Batu \\
\hline 7. & Kemloko & Kabupaten Blitar \\
\hline 8. & Modangan & Kabupaten Blitar \\
\hline 9. & Plumbangan & Kabupaten Blitar \\
\hline 10. & Semen & Kabupaten Blitar \\
\hline 11. & Serang & Kabupaten Blitar \\
\hline 12. & Tulungrejo & Kabupaten Blitar \\
\hline 13. & Karangsari & Kabupaten Blitar \\
\hline 14. & Deling (Negeri Atas Angin) & Kabupaten Bojonegoro \\
\hline
\end{tabular}

${ }^{5}$ Sumber CNN Ekonomi tentang Desa Wisata diakses tanggal 10 Desember 2018. 


\begin{tabular}{|c|c|c|}
\hline 15. & Jono & Kabupaten Bojonegoro \\
\hline 16. & Lombok Kulon & Kabupaten Bondowoso \\
\hline 17. & Gapura Wetan & Kabupaten Gresik \\
\hline 18. & Kemuning Lor & Kabupaten Jember \\
\hline 19. & Payangan & Kabupaten Jember \\
\hline 20. & Besuki & Kabupaten Kediri \\
\hline 21. & Joho - Sumber Podang & Kabupaten Kediri \\
\hline 22. & Sugih Waras & Kabupaten Kediri \\
\hline 23. & Pronojiwo & Kabupaten Lumajang \\
\hline 24. & Ranu Pani & Kabupaten Lumajang \\
\hline 25. & Sendang Duwur & Kabupaten Lamongan \\
\hline 26. & Brumbun & Kabupaten Madiun \\
\hline 27. & Sarangan & Kabupaten Magetan \\
\hline 28. & Bendosari & Kabupaten Malang \\
\hline 29. & Ngadas & Kabupaten Malang \\
\hline 30. & Gubug Klakah & Kabupaten Malang \\
\hline 31. & Pujon Kidul & Kabupaten Malang \\
\hline 32. & Purwodadi & Kabupaten Malang \\
\hline 33. & Sanankerto "Boon Pring" & Kabupaten Malang \\
\hline 34. & Tambakrejo & Kabupaten Malang \\
\hline 35. & Jodipan & Kota Malang \\
\hline 36. & Bejijong & Kabupaten Mojokerto \\
\hline 37. & Claket & Kabupaten Mojokerto \\
\hline 38. & Seloliman & Kabupaten Mojokerto \\
\hline 39. & Ngrayudan & Kabupaten Ngawi \\
\hline 40. & Klayar & Kabupaten Pacitan \\
\hline 41. & Pakis Baru & Kabupaten Pacitan \\
\hline 42. & Watu Karung & Kabupaten Pacitan \\
\hline 43. & Tosari & Kabupaten Pasuruan \\
\hline 44. & Ngebel & Kabupaten Ponorogo \\
\hline 45. & Karang Patih & Kabupaten Ponorogo \\
\hline 46. & Kupuk & Kabupaten Ponorogo \\
\hline 47. & Candi Pari & Kabupaten Sidoarjo \\
\hline 48. & Kera Nepa & Kabupaten Sampang \\
\hline 49. & Kebangsaan & Kabupaten Situbondo \\
\hline 50. & Bancamara & Kabupaten Sumenep \\
\hline 51. & Bumi Semaan & Kabupaten Sumenep \\
\hline 52. & Lombang & Kabupaten Sumenep \\
\hline 53. & Ampel & Kota Surabaya \\
\hline 54. & Kampoeng Maspati & Kota Surabaya \\
\hline 55. & Bangun (Dewi Bangun) & Kabupaten Trenggalek \\
\hline 56. & Dompyong & Kabupaten Trenggalek \\
\hline 57. & Sawahan & Kabupaten Trenggalek \\
\hline 58. & Tasikmadu & Kabupaten Trenggalek \\
\hline 59. & Watu Agung & Kabupaten Trenggalek \\
\hline 60. & Bejagung & Kabupaten Tuban \\
\hline 61. & Geger & Kabupaten Tulungagung \\
\hline
\end{tabular}


Data di atas membuktikan Desa Wisata di Jawa Timur tidak sedikit dan pasti masih ada yang belum tercantum dalam data tersebut. Oleh sebab itu memunculkan permasalahan menarik yang pas untuk dikaji yang akan berkaitan dengan suatu peran wisata edukasi (Kampung Susu Dinasty di Desa Sidem) terhadap peningkatan pendapatan pemerintah desa dan kesejahteraan masyarakat desa. Kampung Susu Dinasty ini sendiri adalah Usaha Kecil menengah (UKM) Kreatif yang pada tahun 2015 yang lalu dikembangkan menjadi lokasi wisata edukasi berbasis perternakan. Tidak hanya menawarkan wisata edukasi untuk anak-anak, Kampung Susu Dinasty ini juga dilengkapi dengan banyak lokasi foto-foto. Tentu saja ini juga menjadi daya tarik tersendiri untuk para muda-mudi. Dan masih banyak lagi yang lainnya yang ditawarkan. Seiring semakin pesatnya tempat-tempat wisata yang didesain selain untuk tempat liburan biasa namun juga memberikan edukasi kepada para pengunjungnya. Destinasi wisata ini masih tergolong baru, tentu pengunjung yang berwisata ke Kampung Susu Dinasty Tulungagung kebanyakan dari masyarakat sekitar saja. Di sisi lain, juga belum banyak media yag mengekspos salah satu destinasi wisata edukasi yang berada di Desa Sidem Kecamatan Gondang Kabupaten Tulungagung ini. Demikian, penelitian mengenai permaslahan yang akan dikaji dan diteliti tersebut penting untuk dilakukan penelitian dengan mengamati agar dapat mengetahui apakah peran wisata berbasis edukasi (Kampung Susu Dinasty Desa Sidem) tersebut sesuai dengan prosedur yang ada dan mempunyai peran terhadap kesejahteraan masyarakat dan peningkatan pendapatan desa, maka peneliti tertarik untuk mengambil judul penelitian : "Peran Kampung Susu Dinasty Dalam Meningkatkan Pendapatan Pemerintah Desa dan Kesejahteraan Masyarakat Desa Sidem Kecamatan Gondang Kabupaten Tulungagung". 


\section{Kerangka Teoritis}

\section{A. Sosial Ekonomi}

Kata sosial berasal dari kata lain "socius" yang dalam bahasa Inggris "society" yang berarti 'kawan'. Maksud kawan disini adalah mereka (orang-orang) yang ada di sekitar, yakni yang tinggal dalam satu lingkungan tertentu dan mempunyai sifat saling mempengaruhi. ${ }^{6}$

1. Aspek Kondisi Sosial Ekonomi Masyarakat

Untuk menentukan kondisi sosial ekonomi masyarakat diperlukan beberapa aspek sebagai penilainya, sehingga dalam penentuan kondisi sosial ekonomi suatu masyarakat dapat ditentukan secara lebih jelas dan pasti. Status sosial ekonomi seseorang dapat dilihat atau dinilai dari beberapa aspek yaitu pekerjaan, pendapatan, kekayaan, tingkat pendidikan, keadaan dan lokasi tempat tinggal serta pergaulan dan aktivitas sosial.

Dari beberapa aspek yang menentukan status sosial ekonomi tersebut, maka dalam penelitian ini hanya akan memfokuskan pada beberapa aspek dari kondisi sosial ekonomi seseorang, yaitu pekerjaan, pendpaatan, tingkat pendidikan dan keadaan tempat tinggal.

a. Aspek Ekonomi

1) Pekerjaan

Pekerjaan adalah kegiatan atau aktivitas yang dilakukan oleh seseorang sehingga memperoleh penghasilan. Jenis pekerjaan

Kategori pekerjaan ada 7, antara lain :

a) Berusaha sendiri, adalah bekerja atau berusaha dengan menanggung resiko secara ekonomis, yaitu dengan tidak kembalinya ongkos produksi yang telah dikeluarkan dalam rangka usahanya tersebut, serta tidak menggunakan pekerja dibayar maupun pekerja tak dibayar, termasuk yang sifat pekerjaannya memerlukan teknologi atau keahlian khusus.

b) Berusaha dibantu buruh tidak tetap/buruh tak dibayar, adalah bekerja atau berusaha atas resiko

${ }^{6}$ Wahyuni Yuyun, Dasar-Dasar Statistika Deskriptif, (Nuha Medika Press, 1986), 60. 
sendiri, dan menggunakan buruh/pekerja tak dibayar dan atau buruh/pekerja tidak tetap.

c) Berusaha dibantu buruh tetap/buruh dibayar, adalah berusaha atas resiko sendiri dan mempekerjakan paling sedikit satu orang buruh/ pekerja tetap yang dibayar.

d) Buruh/karyawan/pegawai, adalah seeorang yang bekerja pada orang lain atau instansi/kantor/perusahaan secara tetap dengan menerima upah/gaji baik berupa uang maupun barang. Buruh yang tidak mempunyai majikan tetap, tidak digolongkan sebagai buruh/karyawan, tetapi sebagai pekerja bebas.

e) Pekerja bebas di pertanian, adalah seseorang yang bekerja pada orang lain/majikan/institusi yang tidak tetap (lebih dari 1 majikan dalam sebulan terakhir) di usaha pertanian baik berupa usaha rumah tangga maupun bukan usaha rumah tangga atas dasar balas jasa dengan meneriman upah atau imbalan baik berupa uang maupun barang, dan baik dengan sistem pembayaran harian maupun borongan.

f) Majikan adalah orang atau pihak yang memberikan pekerjaan dengan pembayaran yang disepakati.

g) Pekerja bebas di non pertanian adalah seseorang yang bekerja pada orang lain/majikan/institusi yang tidak tetap (lebih dari 1 majikan dalam sebulan terakhir), di usaha non pertanian dengan menerima upah atau imbalan baik berupa uang maupun barang dan baik dnegan sistem pembayaran harian maupun borongan.

b. Unsur Sosial

1) Keadaan tempat tinggal

Pengertian tempat tinggal dalam dal ini adalah rumah, Undang-Undang Republik Indonesia Nomor 4 Tahun 1002 Tentang perumahan dan pemukiman, rumah adalah bangunan yang berfungsi sebagai tempat tinggal atau hunian dan sarana pembinaan keluarga. Kemudian pengertian lain dari rumah adalah 
sebuah bangunan, tempat manusia tinggal untuk beraktifitas dan melangsungkan kehidupannya.

c. Kesejahteraan Masyarakat

Pengertian kesejahteraan itu sendiri adalah kondisi manusia dimana orang-orangnya dalam keadaan makmur, dalam keadaan sehat, dan damai. Sehingga untuk mencapai kondisi itu orang tersebut memerlukan suatu usaha sesuai kemampuan yang dimilikinya. ${ }^{7}$

Teori-teori ekonomi sering mengaitkan antara tingginya tingkat kesejahteraan dengan kualitas hidup yang semakin tinggi. Semakin tinggi suatu pendapatan maka akan menyebabkan semakin tinggi pula kesejahteraan yang dilihat dari suatu besarnya konsumsi mereka. ${ }^{8}$

Selanjutnya, konsep pengukuran kesejahteraan yang dikembangkan akhir-akhir ini ialah konsep Human Development Index atau HDI. Konsep HDI diperkenalkan dan dikembangkan sejak tahun 1985. Meskipun dari tahun ke tahun HDI mendapat penekanan yang berbeda-beda, tetapi intinya HDI mengidentifikasikan kemampuan dasar yang harus dimiliki setiap individu dalam masyarakat untuk dapat berpartisipasi di masyarakat. kemampuan dasar tersebut antara lain menyangkut kemampuan untuk dapat mencapai hidup yang panjang dan sehat, kemampuan untuk mencapai ilmu pengetahuan, dan kemampuan untuk mendapatkan akses pada sumber-sumber yang diperlukan dalam angka hidup yang layak. Human Development Index (HDI) ini mempunyai tiga komponen yang menunjukan tingkat kesejahteraan (kemakmuran), yaitu $:^{9}$

1) Angka harapan hidup pada saat lahir (life expectancy at birth),

2) Tingkat pendapatan (income),

3) Tingkat pendidikan (educational attainment),

\footnotetext{
${ }^{7}$ Wardoyo, Kamus Besar Bahasa Indonesia, (Jakarta; Balai Pustaka, 1980), 45.

${ }^{8}$ Koentjaraningrat, Metode Penelitian Masyarakat Edisi Ketiga, (Jakarta; Gramedia

Pustaka Utama,1994), 37

${ }^{9}$ Burhanuddin, Heri, 2013, Hubungan Efektifitas Pengelolaan Program Raskin Dengan Peningkatan Kesejahteraan Masyarakat di Desa Mamahan Kecamatan Gemeh Kabupaten Talaud, Dalam Jurnal Ekonomi Acta Diurna, hal 5.
} 
Badan Kependudukan dan Keluarga Berencana Nasional mengkonsepkan perkembangan kesejahteraan masyarakat desa sebagai ukuran kesejahteraan keluarga/taraf hidup masyarakat, terdiri dari 5 tingkat kesejahteraan, yaitu :10

1) Keluarga prasejahtera (yaitun keluarga yang belum dapat memenuhi kebutuhan dasar minimum seperti kebutuhan pangan, sandang, papan dan kesehatan),

2) Keluarga sejahtera I, yaitu keluarga yang telah dapat memenuhi kebutuhan dasar minimum, tetapi belum dapat memenuhi keseluruhan kebutuhan sosial psikologinya seperti: interaksi dalam keluarga, interaksi dengan lingkungan tempat tinggal, pendidikan dan transportasi,

3) Keluarga sejahtera II, yaitu keluarga yang disamping telah dapat memenuhi kebutuhan dasar minimal, juga kebutuhan sosial psikologinya, tetapi belum dapat memenuhi kebutuhan berkembang/ perkembangannya seperti menabung, memperoleh informasi, transportasi, dan sebagainya.

4) Keluarga sejahtera III, yaitu keluarga yang telah memenuhi seluruh kebutuhan dasar minimal, kebutuhan sosial psikologi.

5) Keluarga sejahtera III-plus, yaitu keluarga yang telah dapat memenuhi seluruh kebutuhannya baik kebutuhan dasar minimal, kebutuhan sosial psikologis, maupun yang bersifat perkembangan serta telah dapat memberikan sumbangan nyata dan berkelanjutan, bagi masyarakat atau pembangunan.

\section{B. Desa Wisata}

Desa wisata adalah suatu bentuk integrasi antara atraksi, akomodasi dan fasilitas pendukung yang disajikan dalam suatu

${ }^{10}$ Burhanuddin, Heri, 2013, Hubungan Efektifitas Pengelolaan Program Raskin Dengan Peningkatan Kesejahteraan Masyarakat di Desa Mamahan Kecamatan Gemeh Kabupaten Talaud, Dalam Jurnal Ekonomi Acta Diurna, hal 5. 
struktur kehidupan masyarakat yang menyatu dengan tata cara dan tradisi yang berlaku. ${ }^{11}$

Fasilitas-fasilitas yang seharusnya ada di kwasan desa wisata antara lain : sarana transportasi, telekomunikasi, kesehatan, dan akomodasi. Khusus untuk sarana akomodasi, desa wisata dapat menyediakan sarana penginapan berupa pondok-pondok wisata sehingga para pengunjung dapat merasakan suasana pedesaan yang masih asli.

\section{Pendapatan Desa}

Pendapatan Desa adalah semua penerimaan uang melalui rekening desa yang merupakan hak desa dalam 1 (satu) tahun anggaran yang tidak perlu dibayar kembali oleh desa. Pendapatan desa meliputi semua penerimaan uang melalui rekening desa yang merupakan hak desa dalam 1 (satu) tahun anggaran yang tidak perlu dibayar kembali oleh desa. Pendapatan Desa terdiri atas kelompok: $:^{12}$

1. Pendapatan Asli Desa (PADesa)

Kelompok PADesa meliputi Hasil Usaha, Hasil Aset, Swadaya, Partisipasi dan Gotong Royong Dan lain-lain Pendapatan Asli Desa. Seluruh Pendapatan yang diterima oleh Bendahara Desa harus disetorkan ke dalam Rekening Kas Desa.

Pendapatan yang masuk kategori Hasil Usaha contohnya adalah pendapatan yang berasal dari Badan Usaha Milik Desa (BUMDesa) pengelolaan pasar desa, dan pengelolaan kawasan wisata skala desa. Pencatatan penerimaan dari BUMDesa berupa penerimaan deviden, hasil RUPS, dan pengumuman laba BUMDesa. Sedangkan untuk pendapatan sewa disertai dengan bukti antara lain kuitansi penerimaan sewa.

2. Transfer Desa

Pendapatan transfer desa terdiri dari Dana Desa, Bagian dari Hasil Pajak Daerah Kabupaten/Kota dan Retribusi Daerah, Alokasi Dana Desa (ADD), Bantuan Keuangan dari

\footnotetext{
${ }^{11}$ Nuryanti Wiendu, Pengantar Desa Wisata (Bandung; Bumi Aksara, 1993), 32. ${ }^{12}$ Sugeng, Suci, 2015, Akuntabilitas dan Transparansi Pertanggung Jawaban Anggaran Pendapatan Belanja Desa, Dalam Jurnal Ilmu dan Riset Akutansi vol 4 no 8 , hal 3.
} 
APBD Provinsi, dan Bantuan keuangan APBD Kabupaten/Kota. Pendapatan Transfer berasal dari pemerintah desa yang menyalurkan dana kepada desa sesuai amanat ketentuan yang berlaku atau bantuan keuangan kepada desa.

3. Pendapatan Lain-Lain

Kelompok pendapatan lain-lain meliputi hibah, sumbangan dari pihak ketiga yang tingkat mengikat dan lain-lain pendapatan desa yang sah. Pelaksanaan penerimaan dari hibah, sumbangan, dan lain-lain pendapatan desa yang sah berupa kas dilakukan melalui bendahara desa. Pendapatan yang diterima dalam bentuk kas tunai tersebut, oleh bendahara desa harus segera disetorkan ke rekening kas desa. Pencatatan penerimaan dari Hibah, Sumbangan, dan Lain-lain Pendapatan Desa yang sah harus disertai dengan bukti yang lengkap dan sah antara lain berupa kuitansi penerimaan.

\section{Pembahasan}

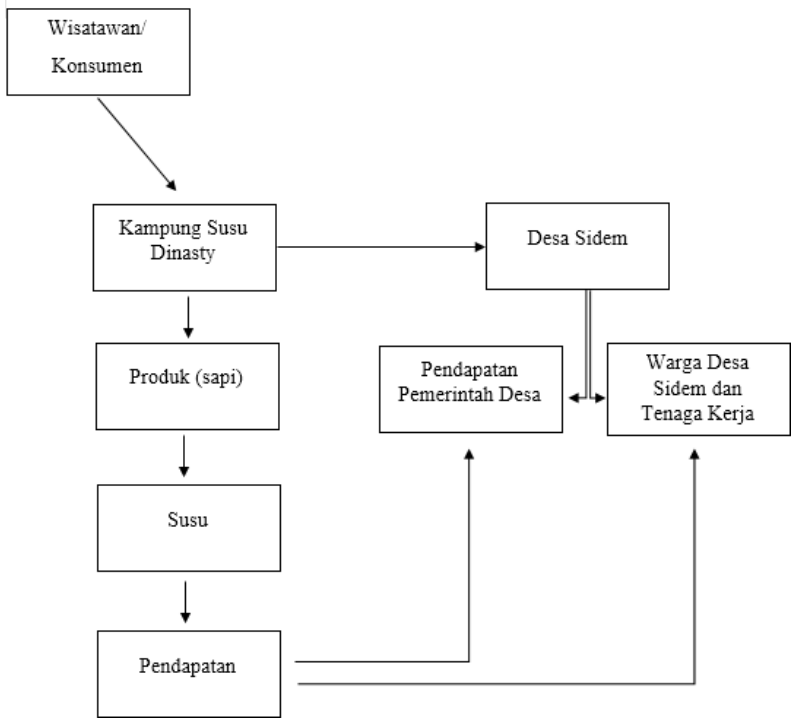

Gambar 3.1 
Berdasarkan gambar alur di atas menjelaskan bahwa Kampung Susu Dinasty dibangun diatas tanah yang berada di desa sidem. Kampung Susu Dinasty ini adalah sebuah usaha dan edukasi yang bergerak pada bidang peternakan yang berupa hewan sapi.

Kampung Susu Dinasty disebut juga desa wisata yang tiap harinya tidak sepi pengunjung atau wisatawan yang ingin menikmati serta beredukasi di desa wisata tersebut. Dari situlah desa wisata ini menjadi ramai dan memiliki pendapatan yang lumayan besar hasil dari penjualan susu maupun tiket masuk wisatawan atau pengunjung. Dengan paket wisata terdiri dari dua macam yaitu paket wisata edukasi dan paket wisata non edukasi. Paket wisata edukasi dengan biaya tiket sebesar Rp 30.000,- saja, sedangkan paket wisata non edukasi hanya berkisar Rp 5.000,-Pada saat menjelang hari libur atau hari minggu pengunjung di Kampung Susu Dinasty bisa mencapai 200- 300 orang (100 orang berwisata non edukasi dan 200 orang berwisata edukasi). Sedangkan pada saat hari biasa (senin- sabtu) pengunjung/ wisatawan mencapai 100-150 orang (50 orang berwisata non edukasi dan 100 orang berwisata edukasi). Maka dapat disimpulkan waktu liburan tiba Desa Wisata Kampung Susu Dinasty mampu memperoleh penghasilan atas kunjungan wisata mencapai Rp26.000.000,- dan disaat hari biasa dalam sebulan Desa Wisata Kampung Susu Dinasty mampu memperoleh penghasilan sebesar Rp.84.500.000,-- Jika penghasilan dari hari libur hingga hari biasa (senin-sabtu) digabungkan maka Desa Wisata Kampung Susu Dinasty memiliki pendapatan per bulan dari pengunjung/ wisatawan mencapai Rp 110.500.000,-.Kampung Susu Dinasty memiliki produk berupa susu dan yoguhurt serta wisata edukasi seperti cara mengelola kotoran sapi agar bisa dimanfaatkan menjadi pupuk kandang, mengetahui proses pembuatan bio gas dari kotoran sapi dan cara memeras susu sapi sampai ke tahap pembuatan susu kemasan yang siap dikonsumsi. 
Penjualan hasil susu dari Kmapung Susu Dinasty ini hanya dijual dikawasan Wisata Kampung Susu Dinasty saja, karena jika dijual diluar maka konsumen tidak akan mengetahui jika pembuatan susu Kampung Susu Dinasty ini ada wisatanya yang beredukasi. Dalam sebulan Kampung Susu Dinasty mampu menjual hasil susunya mencapai 200 liter pada hari libur dan 100 liter pada hari biasa (senin-sabtu). Harga 1 liter susu nya dihargai Rp 20.000,- jika pembeli pada hari libur mencapai 200 liter maka pendapatan perbulan dari penjualan susu mencapai Rp 16.000.000,- dan jika pembeli hari biasa (senin-sabtu) pembeli mencapai 100 liter maka pendapatan perbulan dari penjualan susu mencapai Rp 52.000.000,-. Dapat disimpulkan perbulan Desa Wisata Kampung Susu Dinasty mendapatkan penghasilan dari penjualan susu sebesar Rp. 68.000.000,--

Melihat pendapatan desa wisata Kampung Susu Dinasty yang lumayan banyak tentunya pihak pemilik serta pengelola sudah mengalokasikan dana nya ke masing - masing bagian antara lain laba maupun untuk pajak penghasilan. Untuk laba sendiri, Kampung Susu Dinasty memberikan 25\% dari penghasilan perbulan (kunjungan wisatawan dan penjualan susu) terbagi dalam bidang pengembangan yang berupa edukasi edukasi tentunya untuk selalu meningkatkan dan memajukan desa wisata nya agar bisa menjadi pecontoan model bagi desa desa lain untuk pengembangan desa. Untuk biaya operasional pihak Desa Wisata Kampung Susu Dinasty memeberikan 50\% dari penghasilam perbulan (kunjungan wisatawan dan penjualan susu) digunakan dalam memberikan hak atau gaji kepada para pekerja di Kampung Susu Dinasty yang mayoritas para pekerja nya adalah warga desa sidem sendiri tentunya untuk memberikan lapangan pekerjaaan supaya kehidupan dan kebutuhan masyarakat desa sidem menjadi lebih baik dalam hal kesehatan,pendidikan serta menabung untuk masa depan serta laba desa wisata ini diperuntukan buat keuntungan bagi pemilik desa wisata ini. 
Sedangkan 15\% dari penghasilan perbulan Desa Wisata Kampung susu dinasty akan digunakan untuk meningkatkan produksi susu. Kampung Susu Dinasty ini juga memberikan pendapatan asli desa kepada pemerintah Desa Sidem melalui hasil pendapatan atau omset Kampung Susu Dinasty setiap bulannya yang sebesar sesuai pasal 4 peraturan desa yang sudah disepakati antara pihak Kampung Susu Dinasty dan pemerintah Desa Sidem sebesar 10 \% setiap bulannya, kemudian pemerintah desa mampu mewujudkan desa mandiri karena bisa memperoleh pendapatan asli desa dari Desa Sidem sendiri. Dari hasil penerimaan pendapatan asli desa itu pemerintah desa mengalokasikan ke beberapa program pemerintahan yang diantara nya memberikan berupa fasilitas kepada desa wisata Kampung Susu Dinasty yaitu infrastruktur jalan akses menuju desa wisata Kampung Susu Dinasty agar para wisatawan atau pengunjung yang mendatangi untuk berwisata edukasi ini nyaman dan nyaman, serta diharapkan desa wisata ini selalu ramai dan menjadi icon kabupaten tulungagung bahkan tingkat provinsi jawa timur.

\section{Kesimpulan}

Berdasarkan hasil pembahasan dan penelitian tentang Peran Desa Wisata Kampung Susu Dinasty Dalam Meningkatkan Pendapatan Pemerintah Desa dan Kesejahteraan Masyarakat Desa Sidem Kecamatan Gondang Kabupaten Tulungagung, yang dilakukan oleh penulis maka disimpulkan sebagai berikut :

1. Peran Desa Wisata Kampung Susu Dinasty Dalam Meningkatkan Pendapatan Pemerintah Desa Sidem. Peran desa wisata Kampung Susu Dinasty sangatlah berpengaruh baik dan positif bagi pemerintahan desa khususnya pendapatan Desa Sidem. Kontribusi yang diberikan Kampung Susu Dinasty kepada pemerintah desa sangat besar, sehingga desa sidem mendapat kriteria desa mandiri.

2. Peran Desa Wisata Kampung Susu Dinasty Dalam Meningkatkan Kesejahteraan Masyarakat. Melihat kondisi kesejahteran masyarakat di desa sidem sebelum adanya program Desa Wisata sangatlah kurang baik, segala akses serta infrastruktur belum sepenuhnya terpenuhi di Desa Sidem. 
Mereka mengandalkan hasil pertanian, dan membuat genteng/bata yang hasilnya hanya cukup tanpa adanya tambahan pendapatan untuk menambah tabungan masyarakat.

\section{Saran}

1. Bagi Desa Wisata Kampung Susu Dinasty dalam meningkatkan kesejahteraan Desa Sidem diharapkan mampu mengembangkan potensi masyakarat. Dan benarbenar dioptimalkan serta dikelola dengan baik supaya mampu mewujudkan mimpi Desa Wisata yang maju dan makmur. Program Desa Wisata ini sangatlah bagus bagi kemajuan desa, karena dengan memanfaatkan potendi sumber daya yang ada di desa tersebut dengan sebaik dan semaksimal mungkin akan membuahkan hasil yang sangat luar biasa. Kesejahteraan masyrakat terjamin dan desa menjadi sejahtera.

2. Bagi masyarakat Desa Sidem dalam program Desa Wisata diharapkan mengapresiasikan desanya karena sudah mampu menjadi desa mandiri. Kemudian bisa meminimalisir untuk berniat pergi ke kota-kota besar karena desanya sudah mampu memberi yang terbaik kepada masyarakatnya untuk memenuhi pendapatan rumah tangga.

3. Bagi Akademis adanya Desa Wisata seperti ini yang sedang diperhatikan pemerintah juga, diharapkan pihak akademis mampu memberikan inovasi-inovasi terhadap perkembangan Desa Wisata. Dan memberikan wawasan kepada mahasiswa akan pentingnya pula meningkatkan desa untuk mandiri dan mampu memberikan pemahaman mengenai ekonomi kreatif. 


\section{Daftar Pustaka}

Abdul Syani. Sosiologi Sekematika Teori dan Terapan. Jakarta; Bumi Aksara. 2013

Anak Agung Istri Andriyani, Edhi Martono, Muhamad Pemberdayaan Masyarakat Melalui Pengembangan Desa Wisata Dan Implikasinya Terhadap Ketahanan Sosial Budaya Wilayah (Study di

Desa Wisata Penglipuran Bali). 2017

Ainur, Rofiq. Pertumbuhan Ekonomi dan Kemiskinan. Jakarta; Republika. 2014

Badan Pusat Statistik. go. id diakses pada 10 Desember 2018

Burhanuddin, Heri. Hubungan Efektivitas Pengelolaan Program Raskin

Dengan Peningkatan Kesejahteraan Masyarakat (Dalam Jurnal Study di Desa Mamahan Kecamatan Gemeh Kabupaten Talaud)

Candra Restu, H.B.S. Eko. Perkembangan Desa Wisata Kembang Arum Dan Dampaknya Terhadap Kondisi Sosial Ekonomi Masyarakat (Study di Donokerto Kecamatan Turi). 2016

Destha Titi R. Membangun Pariwisata Bersama Rakyat: Kajian Partisipasi Lokal Dalam Membangun Desa Wisata Di Dieng Plateu (Study di Dieng Plateu). 2012

Eko, Emmelia, Hapsari. Pengembangan Potensi Desa Wisata Untuk Meningkatkan Kesejahteraan Masyarakat (Study Desa Ponggok Kabupaten Klaten). 2017

Fariz Zakaria, Rima Dewi. Konsep Pengembangan Kawasan Desa Wisata (Study di Desa Bandungan Kecamatan Pakong Kabupaten Pamekasan). 2014

Hary Hermawan. Dampak Pengembangan Desa Wisata Terhadap Ekonomi Masyaraka Lokal (Study di Nglanggeran, Gunung Kidul, DIY). 2016 
I Ketut Arnawa, I Wayan Runa, Dkk. Pengembangan Desa Wisata (Study Bayung Gede Kecamatan Kintamani Kabupaten Bangli, Bali). 2016

Kementrian Pariwisata. Tourism Highlights 2015 Edition. Jakarta; Kementrian Pariwisata Indonesia. 2015

Koentjaraningrat. Metode Penelitian Masyarakat Edisi Ketiga. Jakarta; Gramedia Pustaka Utama. 1994

Made Heny, Chafid, Baiquni. Pengembangan Desa Wisata Berbasis Partisipasi Masyarakat Lokal (Study Desa Wisata Jatiluwih Tabanan, Bali). 2015

Nurulitha Andini. Pengorganisasian Komunitas Dalam Pengembangan Agrowisata Di Desa Wisata (Study di Desa Wisata Kembangarum, Kabupaten Sleman). 2013

Nuryanti, Wiendu. Pengantar Desa Wisata. Bandung; Bumi Aksara. 1993

Rafael Modestus. Partisipasi Masyarakat Desa Komodo Dalam Pengembangan Ekowisata Di Pulau Komodo (Study Desa Komodo, Pulau Komodo ). 2015

Sugeng, Suci. Akuntabilitas dan Transparansi Pertanggung Jawaban Anggaran Pendapatan Belanja Desa (Dalam Jurnal Ilmu dan Riset Akutansi)

Sugiyono. Metode Penelitian Kuantitatif Kualitatif dan RED. Bandung; Alfabeta. 2019

Suwigyono. Administrasi Pembangunan Desa dan Sumber-Sumber Pendapatan Desa.Jakarta; Ghalia Indah. 1985

Wahyuni Yuyun. Dasar-Dasar Statistika Deskriptif . Nuha Medika Press. 1986 
Wardoyo. Kamus Besar Bahasa Indonesia. Jakarta; Balai Pustaka. 1980

Wasistiono, Sadu dan Irwan Tahir. Prospek Pengembangan Desa

$\begin{array}{lll}\text { (Study di } & \text { Tajinagor). }\end{array}$


Peran Desa Wisata Kampung Susu

Dinasty

Volume 4, No. 1, Des 2019| 88 